Bangladesh J. Plant Taxon. 20(1): 27-38, 2013 (June)

(C) 2013 Bangladesh Association of Plant Taxonomists

\title{
DIVERSITY OF STOMATA AND TRICHOMES IN EUPHORBIA L. - I
}

\author{
N. Sarojini Devi, Y. Padma, C.L. Narasimhudu and R.R. Venkata Raju ${ }^{1}$ \\ Biosystematics and Phytomedicine Division, Department of Botany, \\ Sri Krishnadevaraya University, Anantapur - 515 055, Andhra Pradesh, India
}

Keywords: Euphorbiaceae; Euphorbia; Epidermal studies; Classification.

\begin{abstract}
Foliar epidermal features of 18 species of Euphorbia L. s.l. (Euphorbiaceae) are studied. While the anisocytic and anamocytic stomata are common in herbaceous members (Euphorbia subg. Chamaesyce), the paracytic type is predominant in succulent species (Euphorbia proper). The stomatal types, index and frequency, and the types of trichomes are explored on vegetative as well as floral parts to evaluate their possible taxonomic importance.
\end{abstract}

\section{Introduction}

Sufficient interest seems to have been revived during the past two decades on the role of internal organization of the individual organs of plants. Leaves occupy a prominent position in this regard and their various features such as venation, stomata and trichomes were found useful in solving taxonomic and phylogenetic issues. The utility of foliar epidermal features in distinguishing taxonomic groups was clearly established (Stace, 1965, 1984; Dilcher, 1974; Raju, 1981; Rao and Raju,1985, 1988; Mohan, 1994; Manohari, 2004).

In view of the above considerations, it was thought worthwhile to investigate the epidermology of the important genus Euphorbia L. s.l., with 84 species occurring in India (Binojkumar and Balakrishnan, 2007, 2010). The great diversity in habit and adaptation exhibited by the species of the genus Euphorbia provide the added impetus for undertaking the present study. The structural diversity and distribution of trichomes are significant for taxonomic analysis, especially in tropical plants (Stace, 1965; Dilcher, 1974; Rao and Raju, 1985). The distribution and structure of trichomes and stomata are genetically controlled and consistent. The useful epidermal characters in systematics are the distribution of stomata over the two surfaces of the leaf, stomatal index and frequency, the nature of anticlinal walls of the epidermal cells and the types and distribution of trichomes. To fill the gaps in our knowledge in this regard concerning the genus Euphorbia sensu Linnaeus in India, the present study was undertaken. It is also intended to view whether these data support the realignments in the genus Euphorbia by Yang et al. (2012) with regard to the traditional subgenera Eremophyton and Poinsettia.

\section{Materials and Methods}

In the present investigation, 18 species of Euphorbia L. s.l. were studied for the organography of epidermal features (Table 1). The plant materials used in the present study were mostly shade dried and of pressed specimens. Whole plants were boiled in water with a few pellets $(1 \mathrm{~g})$ of $\mathrm{NaOH}$ at $30-40^{\circ} \mathrm{C}$. The peels were thoroughly washed and stained with safranin or acetocarmine and mounted in glycerin. The epidermal features such as cuticle, epidermal cells, stomata, and trichomes were observed on all the organs and measured using Nikon Eclipse, E-400 microscope.

\footnotetext{
${ }^{1}$ Corresponding author. Email: rrvenkataraju@yahoo.com
} 
Ocular micrometer was used for measurement. The terminology adopted for the epidermal features is after Raju and Rao $(1977,1987)$ and Raju (1981). The species of Euphorbia studied were identified with the help of standard regional floras and experts (Ellis, 1990; Venkataraju and Pullaiah, 1995; Babu, 1995; Binojkumar and Balakrishnan, 2010), and the voucher specimens were deposited in the Sri Krishnadevaraya University Herbarium (SKU), Anantapur.

\section{Results}

The epidermis in Euphorbia bears a variety of trichomes and stomata dispersed all over the plant surface in a consistent pattern. The extent of variations in the shape of epidermal cells, nature of anticlinal walls, types of stomata, number of stomata per unit area and stomatal indices, and the types of trichomes (glandular and eglandular) observed in 18 species are documented in Tables 1 and 2.

Eleven species of Euphorbia bear trichomes on vegetative and floral parts and the remaining seven species are glabrous. The epidermal appendages vary in structure, form and distribution. The trichome types presently recorded in the members of Euphorbia are mostly multicellular. However, Euphorbia agowensis (Fig. 1A) bears unicellular cylindrical trichomes on vegetative as well as floral parts. A noteworthy feature of Euphorbia species currently recorded is the presence of glandular trichomes at nodes and bases of stipules. These can be found in E. cristata (Fig. 3A), E. elegans (Fig. 3B), E. hirta (Fig. 3E), E. indica (Fig. 3G), and E. prostrata (Fig. 3D) of subg. Chamaesyce and E. heterophylla (Fig. 3C) of subg. Poinsettia, which are often segregated as distinct genera. These glandular trichomes are multicellular, stalked and found to be species specific in regard to their size, shape and number per unit area. The stem of E. hirta (Fig. 2G) possesses two types of trichomes; they are multicellular forked with cuticular ornamentations and multicellular uniseriate osteolate ones. However, its involucre bears strictly two-celled cylindrical trichomes (Fig. 2H).

The epidermal cells may be rectangular and polygonal in outline. Depending upon the location on the leaf, i.e., the midrib, margin and apex, their shapes tend to vary. The anticlinal walls are straight to variously arcuate.

The anticlinal walls are straight in E. dracunculoides, E. deccanensis var. nallamalayana (Fig. 1M), E. nivulia (Fig.1H), E. perbracteata (Fig. 1L, adaxial) and E. tirucalli (Fig. 1K). Most of the stomatal types noted for Dicotyledonae (Magnoliopsida) are met within the genus, with anamocytic, anisocytic and paracytic being most preponderant or basic (Sehgal and Paliwal, 1974; Raju and Rao 1977, 1987). Stomata of more than one types have been encountered on the same leaf surface in E. hyssopifolia, E. longistyla (Fig. 1I) and E. thymifolia (Fig. 1J), as reported earlier by Raju and Rao (1977, 1987) for the other species of Euphorbia. In E. caducifolia (Fig. 1B) at places, the stomata are just represented by persistent stomatal initials (due to arrested stomatal development c.f. Raju and Rao, 1977). In E. tirucalli, sometimes, the stomatal complex has single guard cell. With regard to the position of stomata to the level of epidermis, different depths of sunkenness have been observed in various succulent Euphorbia species (Fig. 1B, H). Obviously, these epidermal features can be usefully employed for diagnostic purposes in Euphorbia.

\section{Discussion}

The foliar epidermis offers a number of noteworthy taxonomic characters. The biosystematic and taxonomic studies of a number of families established the importence of leaf epidermis (Baranova, 1972; Raju, 1981; Stace, 1984). Although the taxonomists realized lately the importance of micromorphology of the epidermis, the taxonomic monographs are now considered 


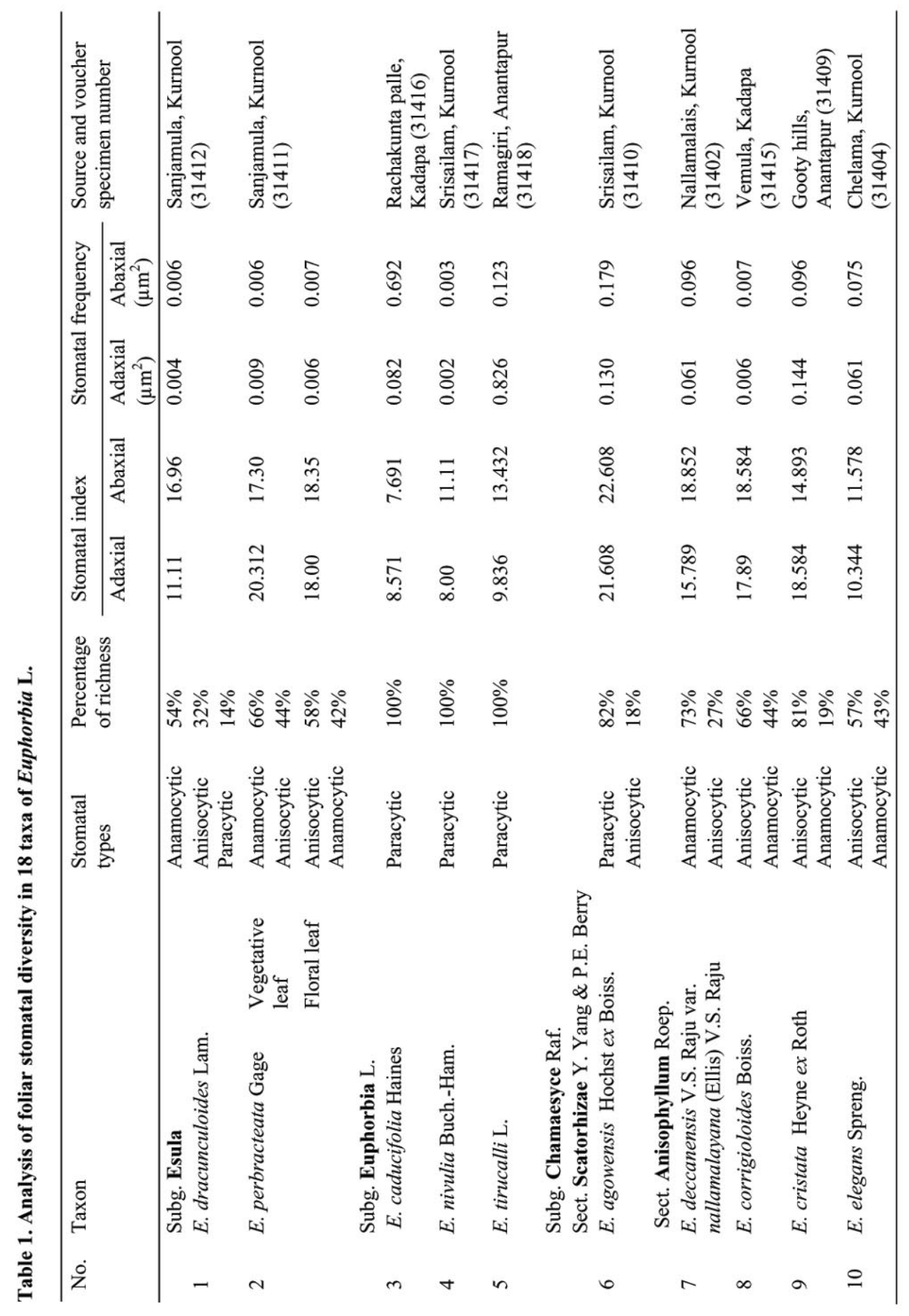




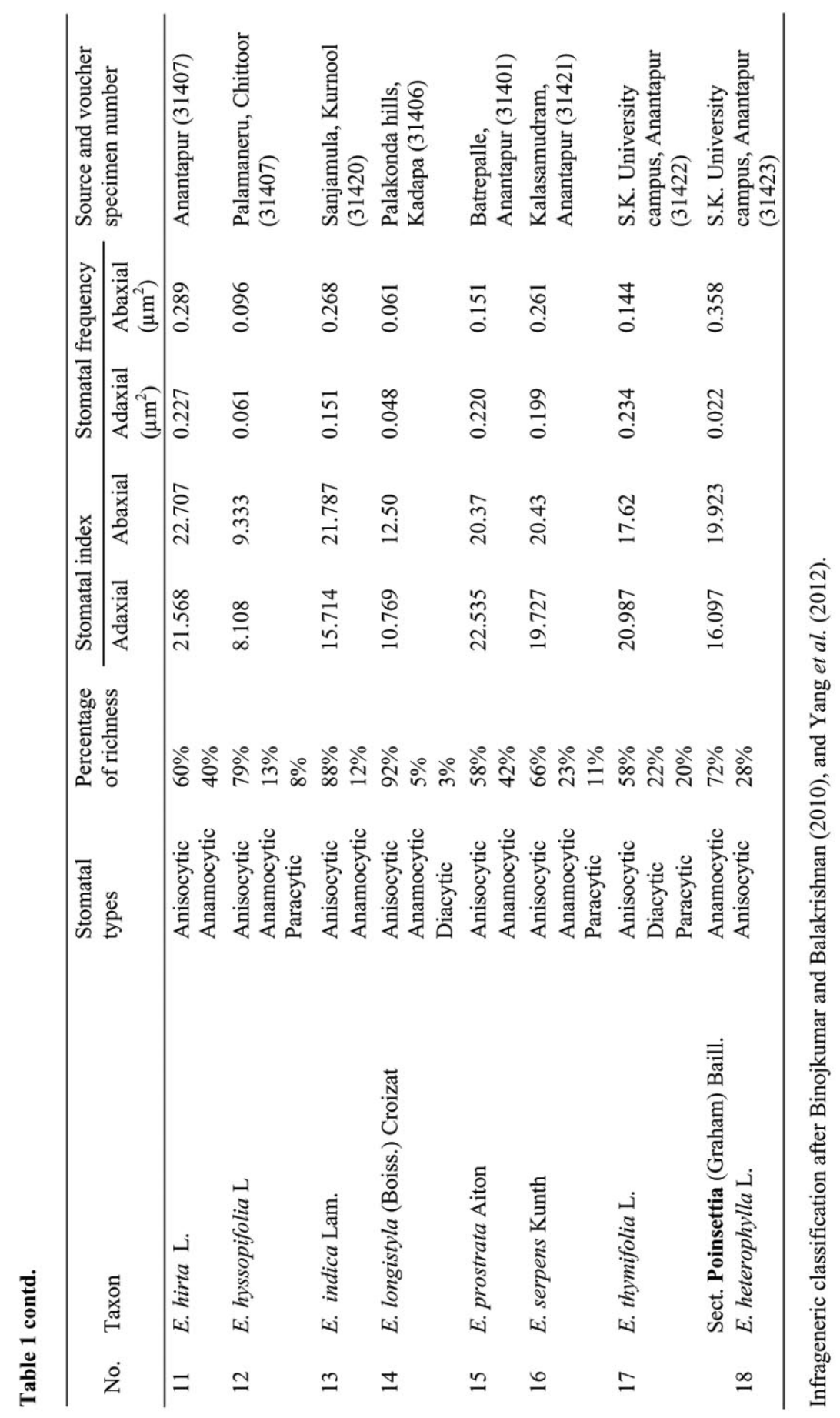




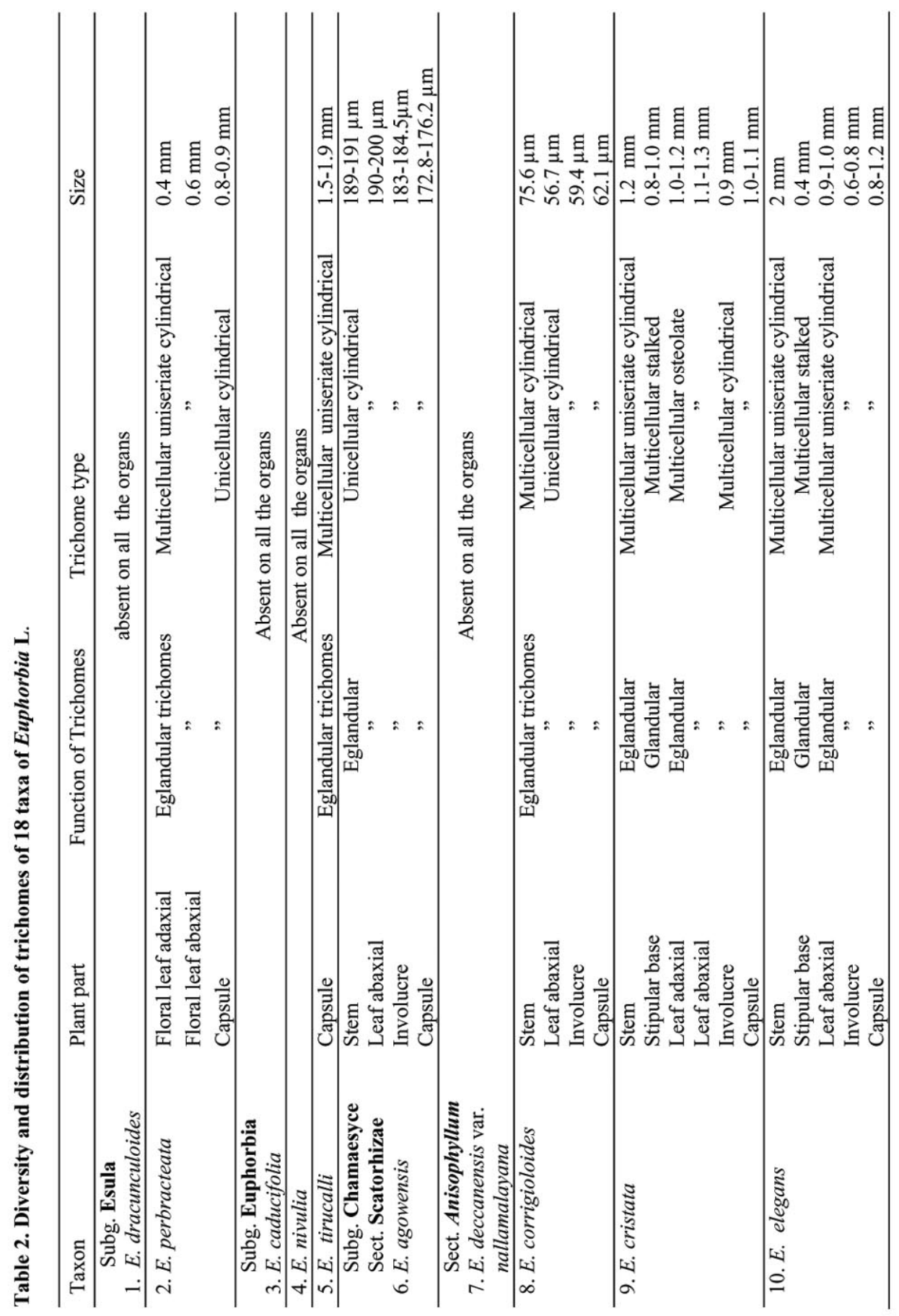




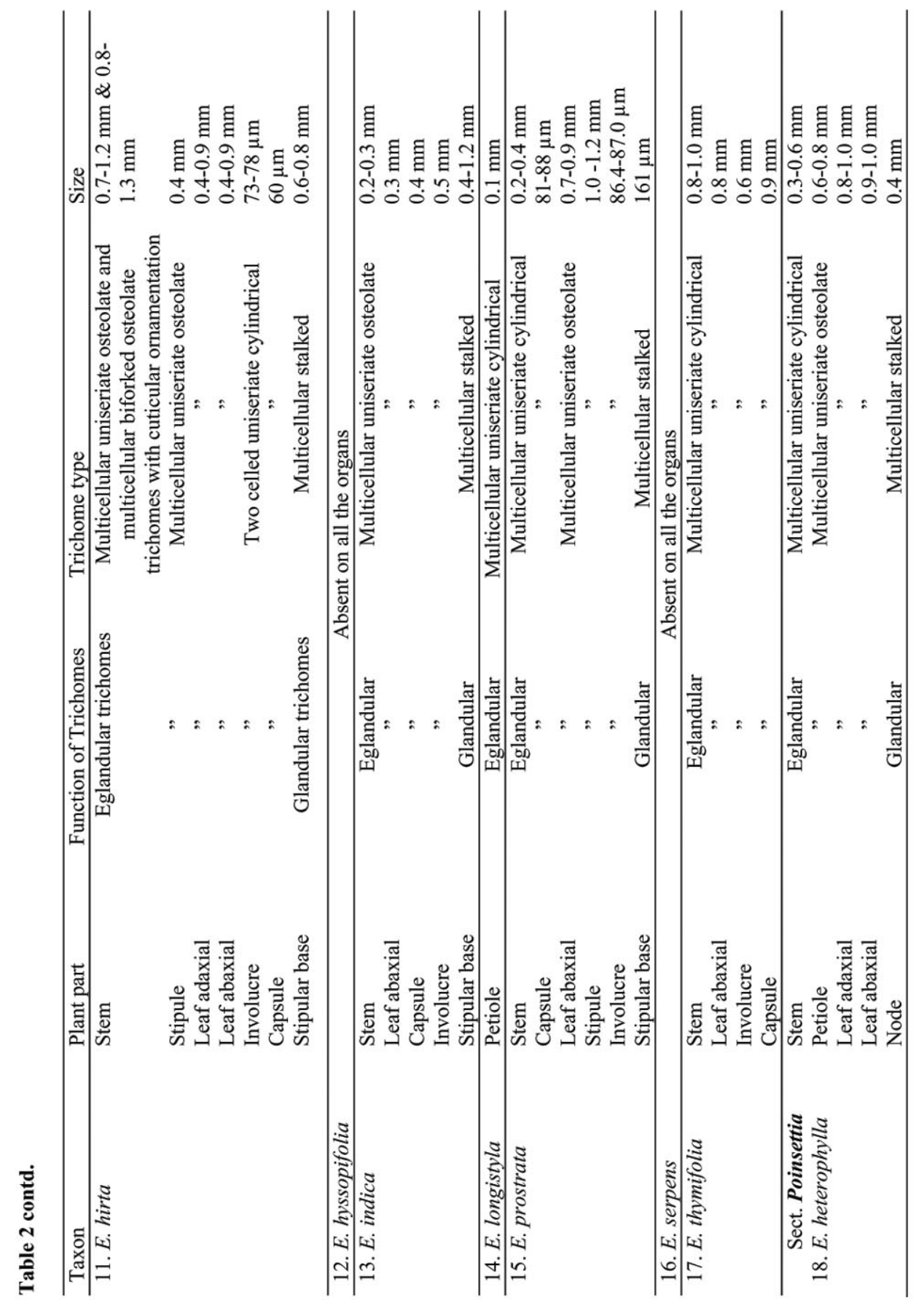




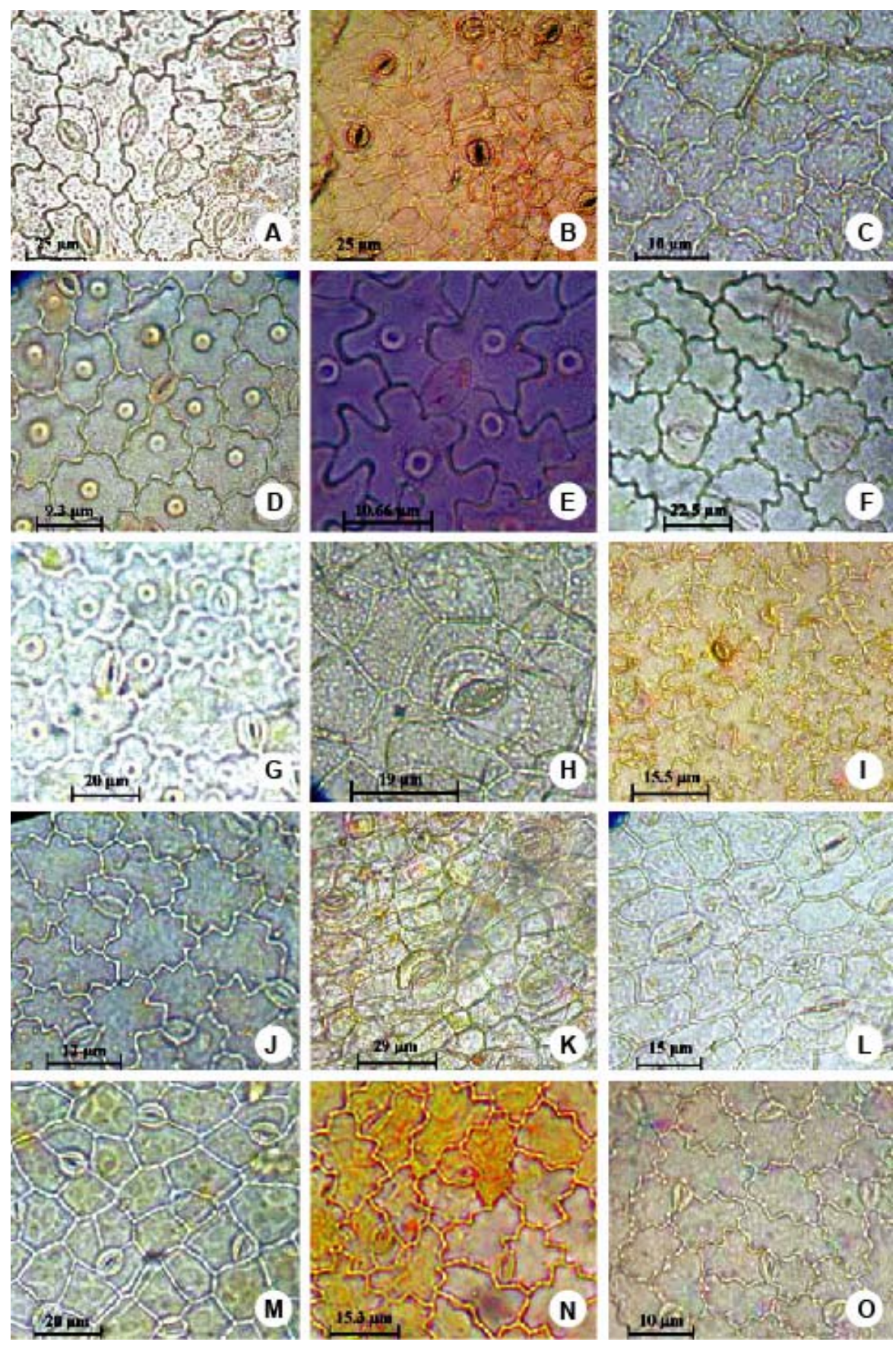

Fig. 1. Organography of epidermal structures in Euphorbia. A) E. agowensis, B) E. caducifolia, C) E. corrigioloides, D) E. cristata, E) E. elegans, F) E. heterophylla, G) E. indica, H) E. nivulia, I) E. longistyla, J) E. thymifolia, K) E. tirucalli, L) E. perbracteata, M) E. deccanensis var. nallamalayana, N) E. prostrata, O) E. serpens. 

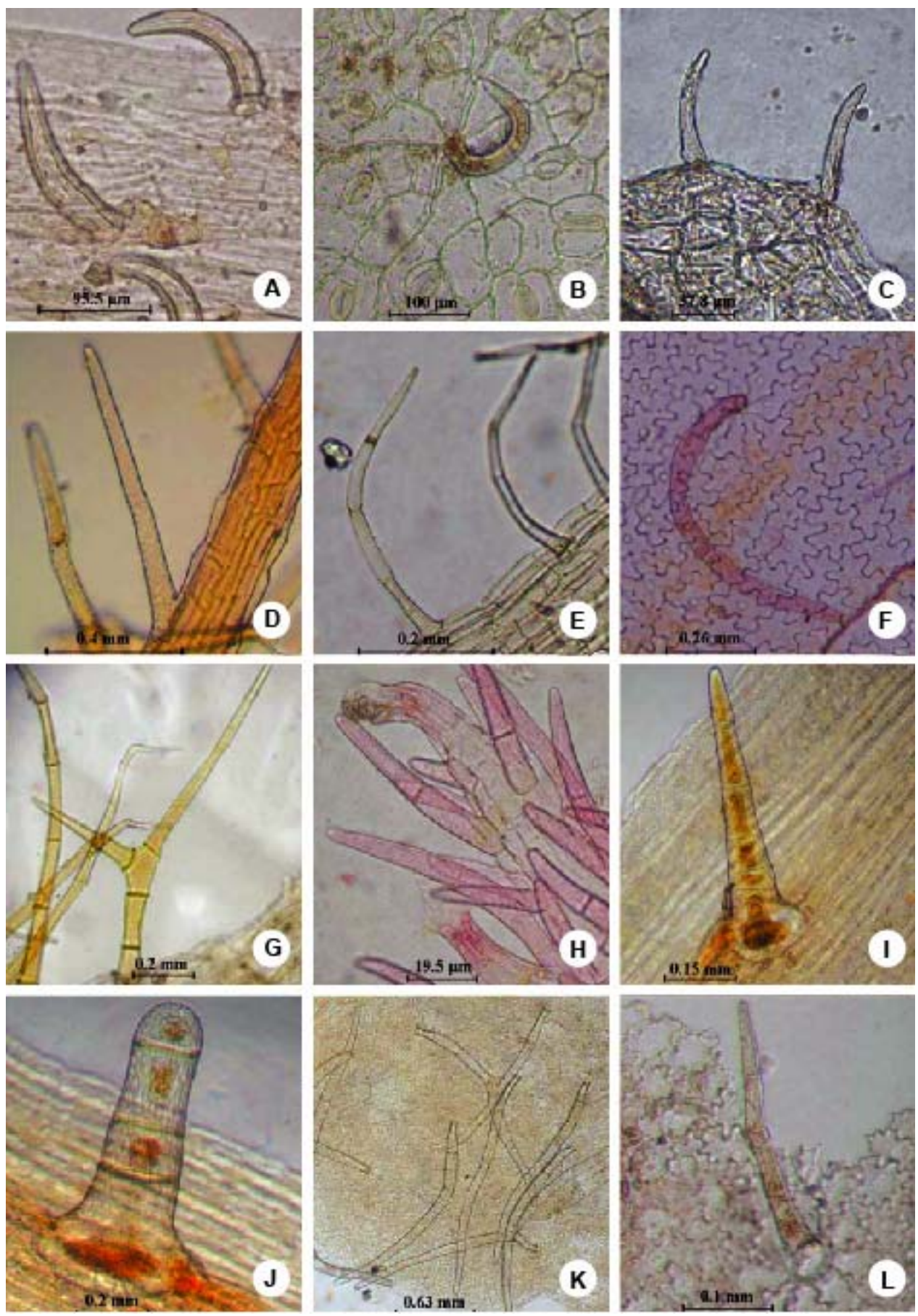

Fig. 2. Trichome diversity in Euphorbia. A) \& B) E. agowensis (stem \& leaf), C) E. corrigioloides (stem), D) E. cristata (appendages), E) E. prostrata (stem), F) E. elegans (leaf abaxial), G) \& H) E. hirta (stem \& involucre), I) \& J) E. heterophylla (stem), K) E. tirucalli (capsule), L) E. indica (leaf abaxial). 
incomplete without it (Rejdali, 1991). The diversity and distributional pattern of stomata and trichomes can be viewed from different perspectives and used as a model system for investigations into developmental biology, ecology, physiology, morphology and evolution.

The work done on the stomata and trichomes was well-documented by Metcalfe and Chalk (1950) and reviewed by Raju and Rao (1977) and Rao and Raju (1985, 1988). The present study fills up the gaps in our knowledge of the other species of the genus Euphorbia after Sehgal and Paliwal (1974), Raju and Rao (1977) and Raju (1981) in India. Different species of Euphorbia have been found to possess anamocytic, anisocytic and paracytic types of stomata, indicating that Linnean Euphorbia is heterogeneous. Therefore, this diversity is of use for infrageneric delimitation. The species of Euphorbia subg. Chamaesyce such as E. hyssopifolia, E. longistyla and $E$. thymifolia showed combinations of two or more types of stomata on the same leaf surface. Despite the variation, a single stomatal type is preponderant in any particular Euphorbiaceous taxon (Raju and Rao, 1977). In the case of Euphorbia subg. Chamaesyce, it is the trilabrate anisomesogenous type. Anisocytic stomata are dominant (Table 1) in the foliar epidermis of $E$. longistyla (92\%) followed by E. indica (88\%), E. cristata (81\%) and E. prostrata (73\%). While anamocytic stomata are predominantly found in E. deccanensis var. nallamalayana (73\%), E. heterophylla (72\%), E. perbracteata (66\%) and E. dracunculoides (54\%), paracytic stomata are preponderant in tree species and shrubs like E. caducifolia, E. nivulia and E. tirucalli (Table 1).

Papillate epidermal cells were found in the abaxial surface of leaves of Euphorbia subg. Chamaesyce, as seen in E. cristata, E. elegans (Fig. 1D, E) and E. indica (Fig. 1G). In E. perbracteata, the anticlinal walls are straight in the adaxial foliar epidermis while they are undulate to highly wavy abaxially, as noted in the other Euphorbiaceae (Raju and Rao, 1977). Similarly, more than seven types of eglandular trichomes and three types of glandular trichomes are found on vegetative and floral parts of the Linnean Euphorbia.

\section{Taxonomic Treatment}

The diversity in stomata and trichomes is useful for infrageneric distinctions. However, their importance as taxonomic criteria will be greatly enhanced if the information can be interpreted with supportive evidence.

Binojkumar and Balakrishnan (2010) recognised 10 subgenera under Euphorbia for the Indian species. The species of Euphorbia studied now belong to five subgenera, viz., Chamaesyce, Eremophyton, Esula, Euphorbia and Poinsettia. Euphorbia subg. Chamaesyce exibits distinct taxonomic features like varied forms of glandular trichomes at stipular bases, more than four types of eglandular trichomes and four types of stomata, whereas the subg. Eremophyton is distinct from the other groups by bearing unicellular trichomes on all vegetative and floral parts, and the predominant paracytic stomata. The subg. Esula shows two stomatal types, the abaxial anticlinal walls wavy and adaxial ones straight, while the subg. Euphorbia is characterized by paracytic and sunken stomata. The subg. Poinsettia exhibits two types of trichomes (eglandular and glandular) and the predominant advanced anamocytic stomata. Yang et al. (2012) based on molecular evidence, re-circumscribed the genus Euphorbia subg. Chamaesyce. They reduced the traditional subgenera Eremophyton and Poinsettia as sections under Euphorbia subg. Chamaesyce. E. agowensis was placed under subg. Euphorbia sect. Scatorhizae. However, E. agowensis is not allied to the core sect. Anisophyllum in its basic stomata and trichome types besides being ecarunculate and non-kranz species (Tables $1 \& 2$ ). As a section, Poinsettia (E. heterophylla) also makes the subg. Chamaesyce heterogeneous with its species bearing coloured floral bracts, basic anamocytic stomata (Table 1) and two types of trichomes on the stem (Table 2). Therefore, the micromorphological evidence supplemented with other morphological data are not in agreement with the re-alignment made for these two sections by Yang et al. (2012), and instead, the data are 

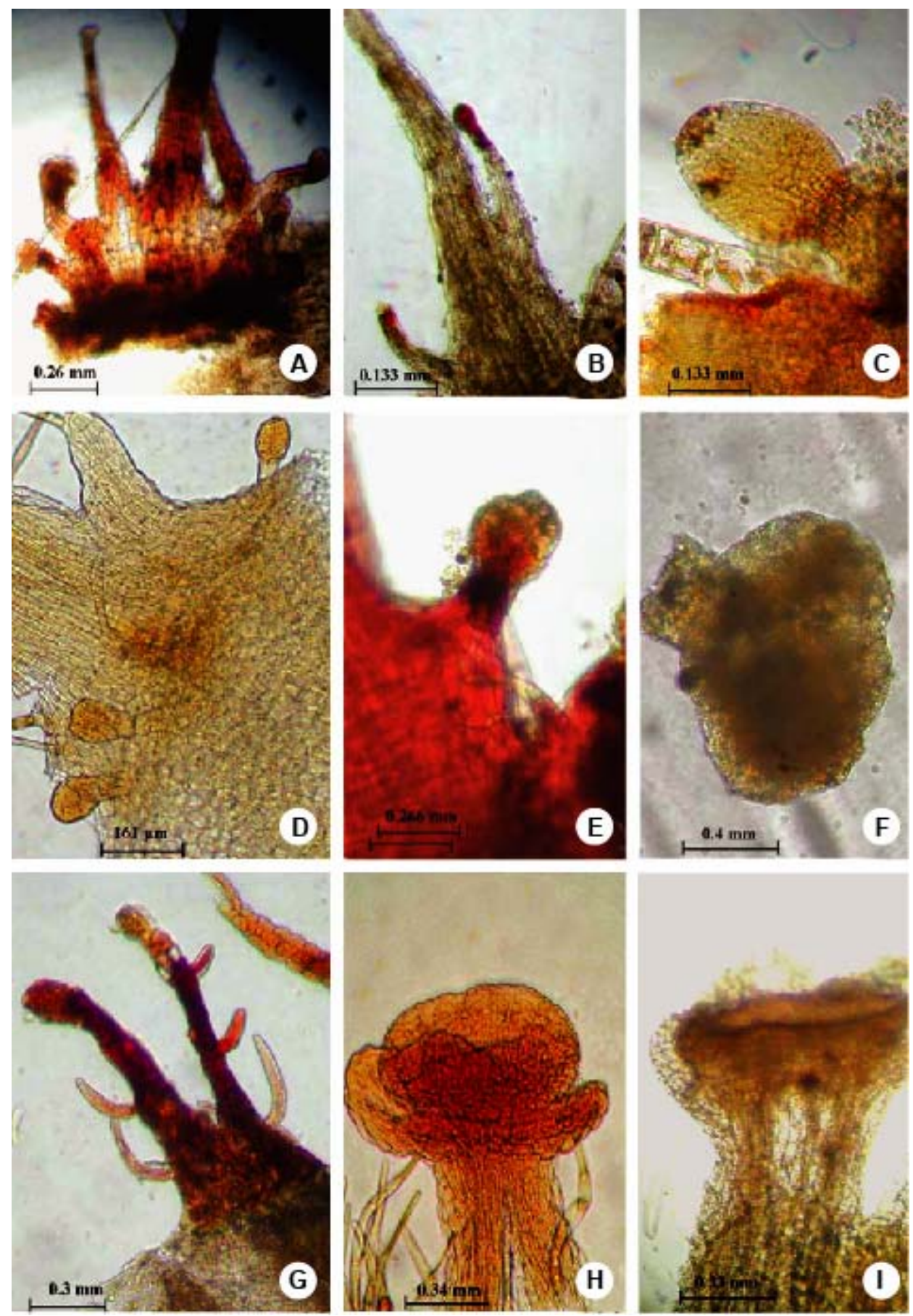

Fig. 3. Vegetative and floral glands in Euphorbia. A) E. cristata, B) E. elegans, C) E. heterophylla, D) E. prostrata, E) E. hirta, F) E. agowensis (leaf), G) E. indica, H) E. prostrata (involucral gland), I) E. serpens (involucral gland). 
compatible with the traditional treatment adopted by Binojkumar and Balakrishanan (2010), for the species examined.

The present study reveals that the epidermal characters are of taxonomic significance in the members of the Euphorbia examined. Despite the fact that the epidermis is being influenced by environmental factors, the traits employed are stable with regard to the mature stomatal type and distribution on different organs. Therefore, the stomata, trichomes and epidermal cells can be effectively used to identify and distinguish different plant species and draw parallels or convergence with the molecular evidence.

\section{Acknowledgements}

The authors are grateful to Prof. Vatsavaya S. Raju, Retired Professor, Department of Botany, Kakatiya University, Warangal, Andhra Pradesh, for his encouragement and inputs and the Forest Officials of Andhra Pradesh for their cooperation and help during the field work. The first author is grateful to the University Grants Commission, New Delhi for financial assistance.

\section{References}

Babu, P.S.P. 1995. Euphorbiaceae of Andhra Pradesh, India. Ph.D. thesis. Sri Krishnadevaraya University, Anantapur, India.

Baranova, M. 1972. Systematic anatomy of the leaf epidermis in the Magnoliaceae and some related families. Taxon 21: 447-469.

Binojkumar, M.S. and Balakrishnan, N.P. 2007. Euphorbia. In: Balakrishnan, N.P. and Chakrabarty, T. (Eds), The Family Euphorbiaceae in India, A Synopsis of its Profile, Taxonomy and Bibliography. Bishen Singh Mahendra Pal Singh, Dehra Dun, India. pp. 238-281.

Binojkumar, M.S. and Balakrishnan, N.P. 2010. The genus Euphorbia L. (Euphorbiaceae) in India: A Taxonomic Revision. Bishen Singh Mahendra Pal Singh, Dehra Dun, India. pp. 1-430.

Dilcher, D.L. 1974. Approaches to the identification of angiosperm leaf remains. Bot. Rev. 40: 1-157.

Ellis, J.L. 1990. Flora of Nallamalais. Vol. 2. Botanical Survey of India, Calcutta. pp. 351-357.

Manohari, A.L.S. 2004. Studies on the Foliar Epidermology, Architecture and Anatomy of some Apocynaceae. Ph.D Thesis, Andhra University, Visakhapatnam, India.

Metcalf, C.R. and Chalk, L. 1950. Anatomy of the Dicotyledons. Vol. 2. Clarendon Press, Oxford.

Mohan, A.C. 1994. Foliar Epidermology and Venation Pattern of Amaranthaceae in Relation to its Systematics. Ph.D. Thesis. Kakatiya University, Warangal, India.

Raju, V.S. 1981. Leaf Architecture as an Aid to the Systematics of the Order Euphorbiales. Ph.D. thesis. Nagarjuna University, Nagarjunanagar, Guntur, India.

Raju, V.S. and Rao, P.N. 1977. Variation in the structure and development of foliar stomata in the Euphorbiaceae. Bot. J. Linn. Soc.75: 69-97.

Raju, V.S. and Rao, P.N. 1987. The taxonomic use of the basic stomatal type in the generic delimitation of Chamaesyce (Euphorbiaceae). Feddes Repert. 98: 137-141.

Rao, P.N. and Raju, V.S. 1985. Foliar trichomes in the family Euphorbiaceae. In: Govil, C.M. and Kumar, V. (Eds), Trends in Plant Research. Prof. Y.S. Murthy Commemorative Volume. Bishen Singh Mahendra Pal Singh, Dehra Dun, India, pp. 128-136.

Rao, P.N. and Raju, V.S. 1988. On the distribution of cuticular markings on the foliar epidermis of the Euphorbiales. J. Econ.Taxon. Bot. 12: 135-137.

Rejdali, M. 1991. Leaf micromorphology and taxonomy of North African species of Sideritis L. (Lamiaceae). Bot. J. Linn. Soc. 107: 67-77.

Sehgal, L.S. and Paliwal, G.S. 1974. Studies on the leaf anatomy of Euphorbia VII. General conclusions and systematic considerations. Phytomorphology 24: 141-151.

Stace, C.A. 1965. Cuticular studies as an aid to plant taxonomy. Bull. Br. Mus. Nat. Hist. 4: 1-78. 
Stace, C.A. 1984. The taxonomic importance of the leaf surface. In: Herwood, V.H. and Moore, D.M. (eds.), Current Concepts in Plant Taxonomy. Systematic Association Special Vol. 25, Academic Press, London. pp. 67-94.

Venkataraju, R.R. and Pullaiah, T. 1995. Flora of Kurnool (Andhra Pradesh). Bishen Singh Mahendra Pal Singh, Dehra Dun, India. pp. 412-418.

Yang, Y., Riina, R., Morawetz, J.J., Haevermans, T., Aubriot, X. and Berry, P.E. 2012. Molecular phylogenetics and classification of Euphorbia subgenus Chamaesyce (Euphorbiaceae). Taxon 61(4): 764-789.

(Manuscript received on 12 July 2012; revised on 9 November 2012) 